\title{
Mendengar dengan Mata Berkatekese dalam Ecclesia Domestica
}

\author{
Paul Kaluge a,1 \\ STFT Widya Sasana, Malang, Jawa Timur ${ }^{\mathrm{a}}$ \\ pkaluge58@gmail.com ${ }^{1}$
}

\section{Keywords:}

Grounded Theory, interaction, ecclesia domestica, hearing vision, Gestalt, Model Katekese Aleph, fenomen, information, transformation, performation.

\begin{abstract}
This article talks about "doing catechesis in ecclesia domestica from Grounded Theory's Perspective." Learning the form (Gestalt) of silence in Eastern tradition in terms of Hebraic tradition in the Sacred Scripture, we find out that human-divine interaction in the first Hebrew alphabet of aleph is a simple, relevant and attractive model. Parents can use it in doing catechesis with their kids under five years old. Translanguaging proses in this period requires parents to learn something from their kids. Parents became "students" of their kids. In this very young age, their kids are the live and the holy text (data). "Catechesis Model of Aleph," as we prefer to say it, will be bring the kids to parents, and by doing this the kids will bring the parents to the kids own-selves as well. This catechesis model is a learning model, not a teaching one. Through "hearing vision" besides "seeing voice," the parents as well as the kids will be sensitive enough to distinguish "I" from "me" - the basic interaction form in every person. However, human-divine interaction represented by aleph is spiritual. In human life experience, is the aleph discovered or invented? Aleph is just an alphabet, but what it points to is really unsayable. As a human-divine interaction, by the way, aleph is the basic model of doing catechesis. This model can inform, perform, and even transform human soul. Parents as well as kids can enter into this human-divine interaction to experience and understand human languaging. The form (Gestalt) is there. It enters, it changes, and it transcendends human life. "Hearing vision" (mendengar bentuk dalam ruang penglihatan) is a dramatic praxis in daily life.
\end{abstract}

\section{PENDAHULUAN}

Ada apa dalam ecclesia domestica yang patut dipelajari dalam berkatekese? Interaksi orangtua-anak merupakan salah satu fenomen. ${ }^{1}$ Pengalaman (experiencing) 
dan pengertian (understanding) dalam interaksi itu membuka ruang yang lebar untuk pembelajaran.

Bahasa memungkinkan orang "melihat ketika mendengar" (= melihat dengan telinga), dan "mendengar ketika melihat" (mendengar dengan mata). Fenomenfenomen dalam interaksi orangtua-anak terbuka untuk dikenal lewat mata dan telinga, karena bahasa. Metafora (gambar $=$ imago $=$ tzelem $)$ dan simile (keserupaan $=$ similitudo $=$ demut ) merupakan instrumen efektif dari bahasa. Instrumen ini juga ada dalam interaksi orangtuaanak dalam ecclesia domestica. Mereka mengatakan (tanpa menunjukkan) sesuatu dan menunjukkan (tanpa mengatakan) sesuatu dalam kaitan dengan sesuatu yang lain. Poros paling fundamental dalam setiap pribadi adalah "I-me" (diri subyektif - diri obyektif).

Katekese tidak tertambat di poros psikologis dan antropologis "I-me" yang ada dalam setiap pribadi. Ekspresi linguistik seperti nefesh, ruach, neshamah, chaya, yechidah dalam Kitab Suci itu, misalnya, menunjukkan bahwa ada level kerohanian yang melampaui psikologi dan antropologi. Karena itu interaksi Allah-manusia (divinehuman = ilahi-insani) juga terbuka untuk dipelajari.

Interaksi ilahi-insani (Allah-manusia) merupakan poros katekese. Ada aksi

kemudian dipikirkan kembali pada abad ke-19 hingga dewasa ini oleh Rudolf Herman Lotze (1817-1881), Carl Stumpf (18481936), Edmund Husserl (1859-1938), Alexius Meinong (18531920), Anton Marty (1847-1914), Adolf Reinach (1883-1917), dan dimatangkan oleh Ludwig Wittgenstein (1889-1951), lalu dikembangkan Roderiock Chisholm (1916-1999), John Pollock, Reinhardt Grossman, Avin Plantinga, Ramon Lemos, dan David Amstrong, sebagaimana diselidiki oleh Matthew Roberts, konsep "fenomen" yang menjadi penting dalam fenomenologi Husserl itu tidak bisa lagi dipahami sekedar sebagai "gejala." Lih. Matthew Roberts, "A Historical Survey and Conceptual Account of States of Affairs," (Ph.D. diss., University of Colorado, Denver, 2006). "belajar" dan "mengajar" dalam poros itu. Sebagai kegiatan pendidikan iman, katekese perlu melewati instruksi-instruksi iman proposisional (iman seperti diungkapkan dalam proposisi-proposisi dogmatis). Pendidikan iman perlu melewati proposisiproposisi itu dan melihat sesuatu yang ditunjukkan di sana. Jika tidak demikian, bagaimana "mukjizat sebagai anak emas dari iman" - menurut ungkapan Rosenzweig -bisa semakin menguduskan manusia dalam drama kehidupan keluarga sebagai Gereja (ecclesia domestica)?

Sebagai "bengkel teologi," keseharian hidup meng-Gereja dalam ecclesia domestica dapat dilihat dalam perspektif Grounded Theori (GT) dan Conceptual Metaphor (CM).

\section{CONCEPTUAL METAPHOR}

"The essense of metaphor is understanding and experiencing one kind of thing in terms of another." ${ }^{3}$ Batasan dari Lakoff dan Johnson ini menyuratkan satu hal dan menyiratkan hal lain. Jadi ada dua hal penting. Pertama (suratan), ada interaksi antara dua hal yang berbeda (one kind of thing in terms of another). Kedua (siratan), ada aksi-aksi dalam interaksi itu, tidak ada aksi tanpa interaksi.

Kita mengenal konsep-konsep, namun bagaimana konsepsualisasinya (interaksinya) sebelum konsep-konsep (aksi-aksi) itu ada? Secara umum, Lakoff memetakan interaksi itu ke dalam target domain (cakupan sasaran: di dalamnya terdapat konsep-konsep yang disebutnya "metaphorical concepts") dan source domain (cakupan sumber: di dalamnya

\footnotetext{
Franz Rosenzweig, "The Star of Redeption," (Wisconsin: The University of Wisconsin Press, 2005), 103.

3 "Esensi metafora adalah mengerti dan mengalami satu hal dalam kaitan dengan suatu hal lain." George Lakoff and Mark Johnson, "Metaphors We Live By," (Chicago: The University of Chicago Press, 1980), 5.
} 
terdapat atribut-atribut yang disebutnya "conceptual metaphors"). Menurut Lakoff, metafora itu bersifat konseptual dan konsep itu bersifat metaforik. Namun, tanpa pengalaman (experiencing) dan pengertian (understanding), maka tidak ada metafora.

Dalaminteraksi kedua domainini--targetsource -- kita mengalami (experiencing) dan mengerti (understanding) aksi-aksi yang terkandung di dalamnya sebagaimana terungkap dalam bahasa sehari-hari. Pandangan ini sedikit berbeda dengan pandangan tradisional tentang metafora.

Metafora tradisional itu figures of speech, figures of thought, atau bahkan figures of faith. Ini berbeda dengan pandangan kontemporer: Metafora itu concepts of speech, concepts of thought, atau bahkan concepts of faith.

Metafora tradisional berporos pada analogy (perbandingan yang proporsional atau berimbang) dan bahasa yang berbungabunga dimanfaatkan untuk menggambarkan perbandingan itu sehingga muncul "figures" (gambar-gambar). Gambaran linguistik (linguistic figures) menjadi dominan. Sedangkan metafora kontemporer berporos pada cognition (interaksi mind-brain). Bahasa memang digunakan, namun bukan bahasa yang berbunga-bunga, melainkan bahasa sehari-hari yang mengandung "concepts" (konsep-konsep).

Analogy: "Kecantikan untuk gadis, keindahan untuk bunga." Perbandingan proporsional ini melahirkan metafora: GADIS ITU BUNGA. Metafora tradisional ini merupakan metafora yang mati (dead metaphor): Metafora tradisional ini terkubur dalam analogy. Lakoff membangkitkan metafora yang mati (dead metaphor) ini dari kuburan analogi. Sesuai pandangan Lakoff, interaksi "gadis-bunga" dalam metafora GADIS ITU BUNGA sangat berbeda dengan interaksi "bunga-gadis" dalam metafora BUNGA ITU GADIS. Interaksi "gadis-bunga" dan "bunga-gadis" mungkin karena ada dinamika orientasi dalam setiap interaksi. Dalam keseharian hidup, aksi-aksi yang keluar dari interaksi ini dapat dialami dan dimengerti dengan mudah:

\section{GADIS ITU BUNGA}

Dia muncul seketika, setelah itu layu.

Di belukar, dia indah di antara semak duri.

Di padang, dia bercahaya di antara bebatuan.

Di taman, dia biasa-biasa saja.

Anda tergoda memetiknya?

Anda merusak keindahan.

Ketika atribut bunga ditempelkan kepada seorang gadis, maka gadis itu menjadi pasif, statis, dan mati dalam bunga. Aksi-aksi yang terjadi adalah: Orang lain akan gampang saja mencemerlangkan terangnya di tengah kegelapan, meredupkan cahayanya di tengah gemerlapan, merelatifkan kecantikannya di tengah keceriaan, dan bahkan merusak dan mematikan kemolekannya dalam sekejap. Namun konsepnya akan berubah jika BUNGA ITU GADIS. Gadis itu hidup, aktif dan dinamis. Aksi-aksi yang terjadi bisa dialami dan dimengerti dalam ekspresiekspresi seperti ini:

\section{BUNGA ITU GADIS}

Jangan sentuh aku

Mau melecehkanku?

Kamu ramah, aku baik.

Kamu binal, aku galak.

Mulai kalau berani!

Ekspresi-ekspresi ini merupakan atribut-atribut personifikasi yang ditempelkan kepada sekuntum bunga untuk menunjukkan sesuatu yang menghidupkan, mengaktifkan dan menguatkan perempuan. Perempuan menantang lelaki yang mau mengobyekkannya, merendahkannya, dan bahkan melecehkannya. 
Pada GADIS ITU BUNGA, konsep "gadis" itu sangat metaforik, dan metafora "bunga" itu sangat konseptual. Pada BUNGA ITU GADIS, konsep "bunga" itu sangat metaforik, dan metafora "gadis" itu sangat konseptual. Ini menunjukkan bahwa dalam keseharian, manusia mengalami dan mengerti sesuatu bukan saja dalam diri hal itu sendiri, melainkan juga dalam keterarahan satu terhadap yang lain. Keterarahan ini memungkinkan interaksi, dan dari interaksi itu manusia mengalami dan mengerti berbagai aksi yang keluar dari interaksi itu.

Cognition itu mengandaikan keterarahan ruang (spatial orientations), dan aksi-aksi dalam interaksi itu merupakan dinamika dalam waktu yang melampaui ruang. Orientasi ini membuat Ding (sesuatu yang berorientasi ke dirinya sendiri) menjadi Sach (sesuatu yang berorientasi ke sesuatu yang lain), menurut Ludwig Wittgenstein. Orientasi memungkinkan adanya "Tatsachen (perkara dalam ruang fisik yang dialami dan dimengerti sebagai dunia), Sachverhalten (duduk perkara dalam ruang logis yang dialami dan dimengerti sebagai fakta), dan Sachlage (inti perkara sub specie aeterni, suatu pengalaman subyek mampu melihat fakta dan dunia seperti Tuhan sendiri melihatnya). ${ }^{4}$ Sachlage itu terjadi

Ludwig Wittgenstein, Tractatus Logico-Philosophicus (London: secara kebetulan, dan pengalaman serta pengertian akan kenyataan ini mengubah cara mengalami dan memahami fakta dan dunia. Melihat segala sesuatu "sub specie aeterni" seperti berada dalam posisi Sang Pencipta yang memandang ciptaan-Nya. Sachlage ini merupakan pengalaman yang mengherankan. Bagi orang beriman, inilah “anak emas" imannya. Sachlage itu (seperti) mukjizat yang mengubah kehidupan.

Tentang cognition perlu disimak dengan lebih jeli karena hal ini sangat membantu untuk memahami "interaksi" yang melahirkan berbagai aksi dan "konsepsualisasi" yang melahirkan berbagai konsep, serta "Sachlage" itu sendiri. Pertanyaan dari Juval Noah Hahari dalam "Homo Deus - A Brief History of Tomorrow" ini penting untuk memahami cognition (interaksi mind-brain) $:^{5}$

Grafik ini memperkarakan cognition (asal-usul pengetahuan) manusia. Sains berusaha membuktikan bahwa manusia memiliki pengetahuan karena pikiran yang dihasilkan oleh kerja keras otak. Namun Harari berpandangan lain: Otak (brain)

\footnotetext{
Routledge Classic, 2001), 2.0121. Lih. juga nomor yang sama pada Tractatus Logico-Philosophicus, SIDE-BY-SIDE-BYSIDE EDITION, VERSION 0.54 (JUNE 4, 2019), dalam teks asli berbahasa Jerman dan dua terjemahan berbahasa Inggris dari C.K. Odgen dan D.F. Pears-B.F. McGuiness lewat link ini: http://people.umass.edu/klement/tlp/

5 Yuval Noah Harari, Homo Deus: Masa Depan Umat Manusia, (Jakartra: Alvabet, 2018), 131.
}

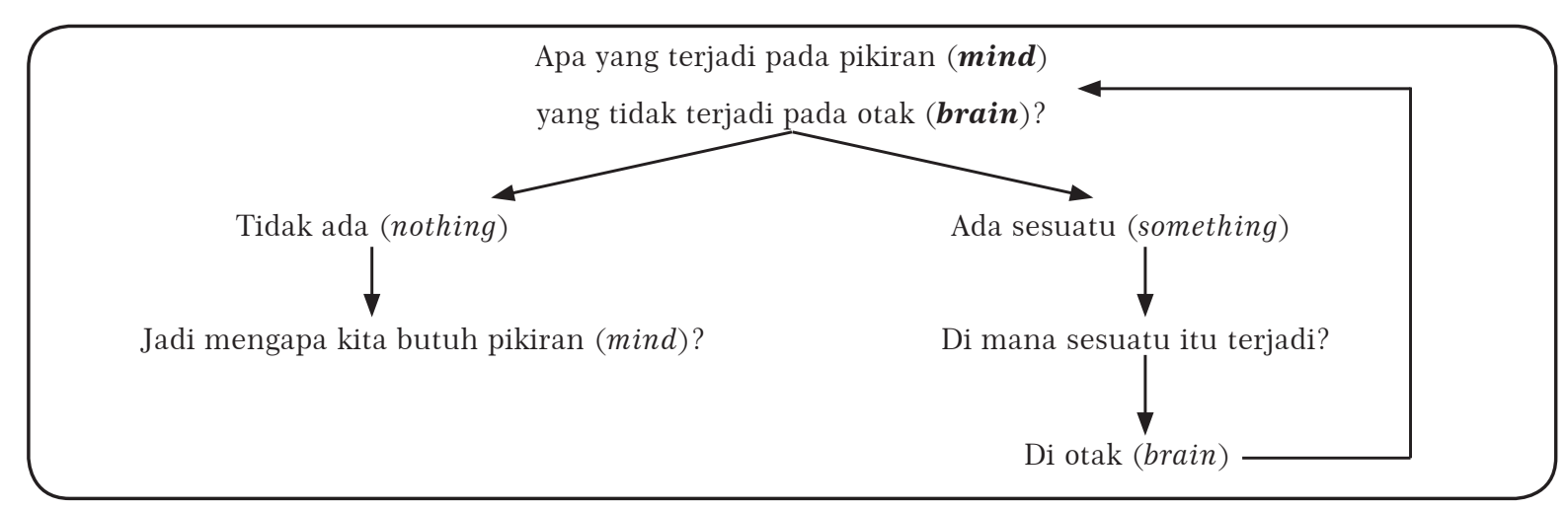


justru bekerja karena ada pikiran (mind). Interaksi mind-brain (cognition) ini memungkinkan adanya pengetahuan.

Di sini menjadi penting untuk membedakan asal-usul (Ursprung $=$ origin $)$ dan awal-mula (Anfang = beginning). Ini pembedaan yang sangat fundamental. Franz Rosenzweig mengatakan: "Beim Wesen fragt man nach dem Ursprung, bei der Tat nach dem Anfang" (Regarding essense, one inquires about origin, but regarding action, about the beginning = Menyangkut esensi, orang memerlukan asal-usul, namun menyangkut aksi, awal-mula). ${ }^{6}$ Berbeda dengan makluk-makluk, hanya manusia yang bisa membedakan keduanya. Interaksi manusia dengan Anfang sangat penting untuk menghasilkan sains dan teknologi. Untuk mengembangkan sains dan teknologi, saintis dan teknolog, tidak memerlukan iman dan mukjizat. Jika teolog dan filsuf mau mengambil posisi saintifik seperti para sains dan teknolog, maka filsafat dan teologinya sangat mungkin bersifat atheistic. Untuk tidak menjadi atheistic, filsuf dan teolog membutuhkan Ursprung. Namun untuk ini, mungkin filsuf dan teolog perlu mengalami apa artinya berhadap-hadapkan dengan kematian untuk bisa berinteraksi dengan kehidupan. Interaksi manusia dengan Ursprung seperti melewati kematian ke kehidupan dalam "Mysterium Paschale," seperti melewati tangga logika kemudian tangga itu dibuang. Inilah pengalaman yang dimaksudkan oleh Wittgenstein dengan istilah Sachlage itu.

Antara Ursprung dan Anfang dalam cognition itu sering menimbulkan pertanyaan: Apakah sesuatu itu diwahyukan

\footnotetext{
Franz Rosenzweig, "Der Stern der Erlösung," (Freiburg: Freiburg im Breisgau, Universitätsbibliothek, 2002), 26. Lih. juga Franz Rosenzweig, "The Star of Redemption," (Wisconsin: The University of Wisconsin Press, 2005), 32.
}

(revealed) atau ditemukan (invented), ditemukan (invented) atau diciptakan (discovered). Lakoff, misalnya, pernah ditanyakan: Apakah matematika itu "invented or discovered?" Pertanyaan yang sama diajukan juga kepada para matematikawan, namun -- berbeda dengan para matematikawan - Lakoff mengatakan bahwa pertanyaan itu keliru, karena cognition tidak bekerja dari penemuan ke penciptaan. Apa yang dipertanyakan Harari di atas itu sangat relevan: Ada sesuatu dalam pikiran (mind) yang tidak ada dalam otak (brain). Pikiran itu bekerja karena ada interaksi. Jadi bukan karena ada pikiran dan sesuatu di dalamnya, melainkan karena ada interaksi di antara keduanya. Lantas, sesuatu itu Ursprung ataukah Anfang?

Pengalaman menunjukkan (dan tidak mengatakan) bahwa sesuatu itu adalah Ursprung. Pemikiran mengatakan (dan tidak menunjukkan) bahwa itu adalah Anfang. Pengalaman tentang interaksi itu sangat mistis. Pemikiran tentang interaksi itu sangat logis. Yang mistik lebih berperan dalam similitudo (simile), dan yang logis itu lebih berperan dalam imago (metafora). Namun secara ilmiah, Lakoff tidak berbicara tentang simile. Dia lebih senang berbicara tentang metafora, dan bersama Rafael E. Nunez, mereka menulis "Where Mathematics Comes From" untuk mendemostrasikan bagaimana matematika itu merupakan pikiran yang terejawantah (embodied mind), matematika itu muncul karena metafora: Manusia memberi tubuh kepada pikiran. Belajar melihat tubuh adalah belajar melihat bentuk (Gestalt) dari pikiran itu sendiri.

Dalam bahasa, dua visinya selalu berperan: Bahasa itu obyek dan istrumen. Sebagai obyek, bahasa mengatakan sesuatu. 
Sebagai instrumen, bahasa menunjukkan sesuatu. Jika tubuh matematika adalah angka (bilangan dan tanda yang menjadi simbol karena pikiran), maka tubuh untuk bahasa adalah abjad (huruf dan tanda yang menjadi simbol karena pikiran).

Bagi teologi, mind dalam interaksi mindbrain itu terkait dengan Ursprung. Apakah karena iman atau karena perbuatan manusia diselamatkan, Tuhan tahu orientasi manusia. Bagi science, mind dalam interaksi mindbrain itu sudah cukup sejauh tata aturan logis dari Anfang bisa diproyeksikan dan diterima akal sehat. Saintis yang menoleh ke Ursprung, akan menghasilkan sains yang dicap hoax. Saintis yang berawal dengan Anfang, sekalipun menjauhi Ursprung, akan diorbitkan sebagai saintis sejati. Namun Harari justru menantang saintis (termasuk teolog) ${ }^{7}$ yang menyepelekan Ursprung .

Ursprung harus ada, namun tentangnya tidak ada cara terbaik untuk mengatakannya. "We must pass over in silence" (kita harus diam). Ursprung menunjukkan dirinya dalam "silentium" (silence). Semua orang dipanggil untuk mengalami silence di hadapan Ursprung. Ketika para teolog menulis tentang silence, mereka berusaha menjadi mulut Ursprung: Mereka mendemonstrasikan "sesuatu dalam kaitan dengan sesuatu yang lain.” Pembaca belajar membangkitkan kemampuan "hearing vision" (mendengar dengan mata) and "seeing voice" (melihat dengan telinga). Namun sebelum mata mengamati data untuk didengar telinga, perlu sedikit menengok Grounded Theory.

\footnotetext{
Mukjizat (miracle) adalah anak emas iman (faith), namun iman tidak melaksanakan tugasnya dengan baik sebagai orangtua. Pernyataan dari Rosenzweig ini menantang teolog Katolik, apakah "Mysterium Paschale" sebagai mukjizat terbesar itu Ursprung atau Anfang? Iman membutuhkan pengertian, Ursprung membutuhkan Anfang. Dalam mencari pengertian, jika iman melupakan mukjizat, maka teolog yang mengutamakan Anfang akan ditarik oleh Ursprung dari belakang.
}

\section{GROUNDED THEORY}

Grounded Theory (GT) adalah metodologi untuk mengeluarkan teori (model) dari data. GT merupakan reaksi terhadap Grand Theory (metodologi yang memasukkan data ke dalam teori-teori besar, pikiranpikiran spekulatif, pandangan-pandangan filsafat, atau bahkan konsep-konsep "besar" dari para ilmuwan terkenal untuk menguji kebenaran data-data itu). Ketika pertama kali muncul tahun 1960-an, Berney G. Glaser dan Anselm L. Strauss ingin agar para calon saintis jangan berpikir, tetapi melihat dengan jeli dan mendengar dengan cermat berbagai peristiwa di lapangan. Glaser mengatakan:

"GT is done best in the hands of the novice $\mathrm{PhD}$ and MA candidates because not only of their quest for relevancy, in the face of extant literature that does not fit, work or is not relevant, they are still open to 'whatever', still enthusiastically learning, still unformed in other Qualitative Data Analysis (QDA) methods, lack QDA method identity protection, and their skill development fledgling status is uniquely suited to skill development required in the GT process. Also they have big stakes in doing original research - hence high motivation - and have the modest amounts of time and money to finish in a timely way. Also the novice is more likely to see fresh new patterns in the face of experienced forcing of professional interest patterns. Thus the category build-up in memos seems very original as they fit and are relevant - sensitive and intelligent."

"GT itu berjalan baik di tangan kandidat master dan doktor bukan saja karena pencarian mereka adalah relevansi di tengah tumpukan literatur yang tidak cocok, tidak berfungsi atau tidak relevan, melainkan juga karena mereka masih terbuka ke 'apapun,' masih belajar dengan penuh semangat, masih belum terbentuk dengan metode Analisis Data Kualitatif (QDA = Qualitative Data Analysis), masih belum fanatik dengan identitas metode QDA tertentu, dan status pemula mereka terkait pengembangan keterampilan disesuaikan secara unik dengan pengembangan keterampilan yang dituntut dalam proses GT. Juga, mereka memiliki taruhan besar dalam melakukan riset yang original - dengan motivasi 
Trend ini sesungguhnya mau menggarisbawahi pentingnya pengalaman (experiencing) yang melampaui pengertian (understanding). Data itu dialami dan kemudian dimengerti. Tujuan GT bukan untuk memverifikasi data yang ada - seperti yang dilakukan dalam Grand Theory, melainkan untuk mengeluarkan suatu model sebagai suatu teori baru dari data. Dictum GT sebagaimana dikumandangkan oleh Glaser adalah "all is data" (semua adalah data). Dictum ini senada dengan penyataan M.A.K Halliday (dalam "Funtional Grammar"): "all is text" (semua adalah teks), ${ }^{9}$ atau penyataan Jacques Derrida muda (dalam "Of Grammatology"): "Nothing outside the text" (Tidak ada yang lain di luar teks = semua adalah teks). ${ }^{10}$ Bahasa itu text, bahasa itu data, bahasa itu pergulatan manusia, karena "sesuatu dalam kaitan dengan sesuatu yang lain" terekspresi di dalamnya.

Dalam perkembangan kemudian di tahun 1970-an, terutama terkait kodifikasi data dalam proses analisis, Glaser menyadari perlunya suatu kepekaan teoretis terhadap "gerund" (verbal noun). Kepekaan ini muncul karena pada gerund itu, interaksi antara sedikitnya dua hal yang berbeda dapat dideteksi. Seperti dalam triangulasi ini: to experience - experiencing - experience, orang bisa langsung membedakan antara bentuk infinitif (to experience) dari bentuk gerund (experiencing), dan gerund dari bentuk kata benda (experience). Triangulasi

yang tinggi - dan memiliki dana dan waktu terbatas untuk menyelesaikan tugas pada waktunya. Juga para kandidat ini agaknya lebih mampu melihat pola-pola baru yang segar di hadapan kekuatan orang-orang yang berpengalaman dengan pola-pola kepentingan yang profesional. Karena itu, kategori yang dibangun dalam memo-memo agaknya sangat original karena memo-memo yang dibuat itu memang tepat dan relevan - sensitif dan inteligen." Barney G. Glaser "The Novice GT Researcher," dalam The Grounded Theory Review , vol. 8, no.2 (U.S.A.: Sociology Press, 2009), 1.

9 M.A.K. Halliday, Functional Grammar (London: Routledge, 2014), 3.

10 Jacques Derrida, Of Grammatology (Baltimore: The Johns Hopkins University Press, 1997), 158. ini seperti sebuah triptych (sebuah lukisan utuh dalam tiga panel). Panel pertama adalah bentuk "infinitive" yang tak-terbatas. Panel terakhir adalah bentuk "noun" yang terbatas. Panel tengah - ini panel yang sangat praksis dan dramatis - adalah bentuk "gerund" terbatas sekaligus tak-terbatas. Menghadapi peristiwa, menghadapi interaksi, gerund merupakan alat yang baik untuk mendeteksi aksi-aksi yang keluar dari interaksi (yang membatasi sekaligus dibatasi). Manusia mengalami dan memahami aksi-aksi itu. Dengan gerund, calon saintis akan tetap bertahan pada data. Segala dinamika yang berproses dalam gerund dibidik secara jeli.

Praktis dalam dekade yang sama, ketika GT berkembang dalam bidang studi sosiologi, muncul juga Conceptual Metaphor (CM) dari bidang studi bahasa. Pengaruh studi interdisipliner membuat kedua bidang studi ini menyentuh psikologi, matematika, cognitive sciences, dan lain sebagainya. Relevansi GT-CM untuk studi teologi selalu perlu diupayakan, karena interaksi Allahmanusia bukan teori, tetapi kenyataan hidup orang beriman. Interaksi itu melahirkan berbagai aksi yang bisa dilihat dalam perspektif GT-CM.

Doing theology (berteologi) dalam keluarga sebagai Gereja (ecclesia domestica), kombinasi GT-CM mungkin bisa dimanfaatkan. Dalam perspektif GT-CM sebagai kerangka berpikir, tulisan ini berbicara tentang interaksi Allah-manusia sebagai model berkatekese yang sederhana, relevan dan atraktif terutama bagi anak usia 0-5 tahun.

Pada usia ini, orangtua bukan saja mereka-reka setiap ungkapan anaknya, namun juga mencari cara (model) yang sederhana, relevan dan atraktif agar anaknya yang belum bisa baca-tulis secara sempurna 
itu bisa mendengar dengan matanya yang sangat jeli. Pada usia sedini ini, apa yang terjadi mungkin bisa diungkapkan dalam bentuk gerund ini: "translanguaging." Anak berjuang untuk mengungkapkan sesuatu dalam suara, gerak, dan lain sebagainya. Orangtua menjadi "murid" yang baik karena terus belajar menangkap ungkapan anaknya, dan anak sebagai "guru" yang baik tetap berjuang untuk memperoleh bahasa. Perjuangan anak untuk memperoleh bahasa ini sangat dramatis. Kejelian mata anak balita melihat bentuk (Gestalt) menjadi pelajaran bagi orangtua. GT-CM bisa menjadi frame (bingkai) metodologis bagaimana "imago" (gambar = metafora) dan "similitudo" (keserupaan $=$ simile) mulai diperkenalkan kepada mata anak balita, sekalipun interaksi orangtua-anak terkadang kandas dalam keheningan.

\section{“SILENTIUM" MENURUT AMALADOSS}

Pater Michael Amaladoss S.J. adalah teolog Asia asal Tamil, Nadu, India Selatan. Ketika artikelnya muncul dalam Concilium (2005), dia menjabat direktur Institute of Dialogue with Cultures and Religions di Chennai. Institut ini merupakan sebuah lembaga riset untuk program doktor di Universitas Madras. Minat khusus teolog Asia ini adalah teologi dan spiritualitas India, dialog antara Injil, budaya, dan agamaagama. Artikelnya dalam Concilium 2005/5 berjudul "Silence and God," kami jadikan semacam data bagaimana "mendengar dengan mata" bisa dilihat di dalamnya secara metodologis. Apa sesungguhnya yang berbicara dalam data itu bagi telinga, ketika mata menelusurinya baris demi baris?

\section{Interaksi Allah-Manusia}

Dalam wacana teologis tentang keheningan $($ silence $=$ silentium), Pater Amaladoss menampilkan wajah silentium dari jendela relasi Allah dengan manusia. Sebagai pendahuluan dia mengatakan:

"Theology refers to talk about God and a theology of silence, in which I have been ask to reflect, will have to talk about silence in relation to God. Silence is understood as the absence of speech. It can be mental (thoughts) as well as physical (words). In the context of conversation, silence could be the absence of a response for whatever reason and in whatever way. In the following pages I plan to focus on three areas. Sometimes God seems silent when humans seek to speak to God. Secondly, when humans seek to think of or to speak about God rationally, they eventually have to fall in silent because God is beyond what they can think or say at that level. God transcends language, concepts, and reason. But God seems accessible to imagination, emotion, energy and intuition. The fact that we cannot speak abpout God or to reach out to God through language and reason does not mean that we cannot experience God in other ways. Thirdly, God may also transcend our experience. We experience God as emptiness, as nothing, as nirvana, or sunya."11

Sejak awal sudah jelas bahwa Pater Amaladoss membedakan experience (apa yang dialami) dan thoughts (apa yang

\footnotetext{
"Teologi mengacu pada pembicaraan tentang Allah dan teologi keheningan, di mana saya diminta untuk untuk membuat refkesi, akan harus berbicara tentang keheningan dalam hubungan dengan Allah. Keheningan dipahami sebagai tidak bicara. Tidak bicara secara mental (pikiran) dan secara fisik (kata-kata). Dalam konteks percakapan, keheningan dapat berarti tidak ada tanggapan dengan alasan apa pun dan dengan cara apa pun. Dalam halaman-halaman berikut saya ingin fokus pada tiga bidang. Kadangkala Allah kelihatan diam ketika manusia berusaha berbicara kepada-Nya. Kedua, ketika manusia berusaha untuk memikirkan atau berbicara tentang Allah secara rasional, mereka akhirnya harus bungkam karena Allah melampaui apa yang dapat mereka pikirkan atau katakan pada level ratio. Allah melampaui bahasa, konsep, dan nalar. Namun Allah tampaknya dapat dijangkau lewat imajinasi, emosi, energi dan intuisi. Fakta bahwa kita tidak dapat berbicara tentang Allah atau menjangkau Allah melalui bahasa dan nalar tidak berarti bahwa kita tidak dapat mengalami Allah dengan cara-cara lain. Ketiga, Allah mungkin juga melampaui pengalaman kita. Kita mengalami Allah sebagai kekosongan, sebagai tiada, sebagai nirvana, atau sunyata." Michael Amaladoss, "Silence and God," dalam Concilium 2005/5, 67.
} 
dimengerti), kemudian menguraikan tentang "the silence of God" (keheningan Allah), "the silence of humans" (keheningan manusia), "the silence of the mystics" (keheningan para mistikus), dengan memberi tambahan tentang "the eastern tradition" (tradisi Timur), "The Absolute/God is silence" (Absolut/Allah itu keheningan), dan "the silence of the Buddha" (keheningan Buddha) dalam bingkai experience and thought tersebut.

The Silence of God (Keheningan Allah): "The normal experience of religion is the ongoing contact of humans with God" (Pengalaman normal tentang agama adalah kontak manusia dengan Allah terus menerus), kata Amaladoss. Allah dialami sebagai Pencipta dan Penyelamat. Doa dilihat sebagai seruan kepada Allah untuk memuji, bersyukur, memohon dan menyesal atas dosa-dosa. Lewat para nabi, Allah berbicara. Allah menyatakan diriNya lewat karya penciptaan, perlindungan dan penyelamatan. Namun Kitab Suci juga menunjukkan contoh-contoh ketika Allah diam. Ketika Yesus menjerit dengan suara nyaring dari atas salib -- "My God, My God, why hast thou forsaken me?" (Mat 27:46) -- Allah diam. Ketika Israel menghadapi musuh, Allah diam (Mzm 44). Ketika Ayub tertimpa malapetaka, Allah diam (Ayb 19). Namun Allah juga mengatakan: "Be still and know that I am God" (Mzm 46:11).

Pater Amaladoss menyajikan dua poin refleksinya. Pertama, GOD'S SILENCE IS A CALL TO CONVERSION (keheningan Allah merupakan seruan untuk bertobat). Kedua, GOD'S SILENCE IS A KIND OF TEST (keheningan Allah itu semacam ujian). Ketika Allah kelihatannya diam, manusia condong untuk mengisi ruang kosong dengan bertutur kata. Namun orang yang paham, penuh pengharapan, akan diam dalam penantian.

The Silence of Humans (Keheningan Manusia): Bertolak dari rasionalitas sebagai kekhasan manusia, Pater Amaladoss mempertaruhkan Sang Pencipta untuk diterima atau ditolak. Sang Pencipta ada, dan manusia diam karena tidak bisa mengatakannya. Sang Pencipta itu tiada, dan manusia diam karena tidak ada gunanya berbicara tentang sesuatu yang tidak ada. Atas nama ratio, keheningan manusia tentang Allah melahirkan ateisme, agnostisisme, dan theisme. Keheningan semacam ini bersifat ideologis, bukan teologis. Keheningan manusia yang bersifat teologis tidak diberikan. Pater Amaladoss langsung terjun ke dalam keheningan para mistikus.

The Silence of the Mystics (Keheningan Para Mistikus): "They have an experience of God that is supra-rational, intuitive, emotional, intellectual" (Mereka memiliki suatu pengalaman akan Allah yang suprarasional, intuitif, emosional, intelektual), kata Pater Amaladoss. Santo Gregorius dari Nyssa (sekitar 335-395) menyelami Moses dan menyelidiki hal-hal yang lebih mendalam dari apa yang dapat diobservasi. Dia akhirnya "reaching out to the 'invisible, the incomprehensible,' and seeing God," kata Pater Amaladoss. Santo Yohanes dari Salib (1542-1591) menulis kepada seorang suster Karmel: "Our most important task consists in remaining silent before this great God, silent with our desires as well as with our tongue. He understand only one language that of silent love" (Tugas kita yang terpenting adalah tetap diam di hadapan Allah yang agung ini, tanpa keinginan, tanpa kata-kata. Allah hanya mengerti satu bahasa, bahasa kasih yang hening). Mempelajari berbagai 
ulasan tentang Allah, Santo Thomas Aquinas mendapat penglihatan (vision) dan berhenti menulis. Umumnya diterima, Allah itu melampaui nalar dan intelek, namun terjangkau oleh pengalaman lewat kasih (experience through love).

The Eastern Tradition (Tradisi Timur): Dalam tradisi Cina, Lao Tze mengawali Tao Te Ching dengan mengatakan: "The Tao (Way) that can be told of is not the eternal Tao; the name that can be named is not the eternal name" (Tao yang dapat diucapkan bukanlah Tao yang abadi; nama yang dapat dinamakan bukanlah nama yang abadi). Sang Bijak Cina ini memberi nasehat: "He who knows does not speak, he who speaks does not know" (Yang tahu tidak bicara, yang bicara tidak tahu).

Dalam tradisi India, para filsuf-teolog mengatakan, "neti neti" (bukan ini, bukan ini) untuk menunjukkan bahwa tidak ada nama atau atribut yang dapat kita terapkan pada Yang Absolut. Dikatakan dalam Brihadaranyaka Upanishad: "Roh itu bukan ini, bukan ini. Dia itu tak-terpahami. Dia tahu segalanya, namun tak satu pun yang tahu tentang Dia." Ditegaskan dalam Katha Upanishad: "Atman itu melampaui suara dan bentuk, tanpa sentuhan, rasa, dan keharuman. Dia abadi, tak berubah, dan tanpa awal atau akhir: Sejatinya Dia melampaui penalaran.” Ada juga tradisi yang mengatakan: "Atman atau Roh batiniah itu dialami dalam tidur yang sangat nyenyak, ketika semua indera diam dan tanpa mimpi. Dalam keheningan yang absolut, Atman menunjukkan dirinya atau dialami."

The Absolute/God is Silence (Absolut/ Allah itu Keheningan): Dikisahkan juga dalam Brihadaranyaka Upanishad tentang percakapan Sang Bijak Yajnavalkya dengan Raja Janaka.
Raja tanyakan sang bijak: "Apa yang menjadi terang manusia?"

Sang bijak menjawab: "Matahari."

Sang raja lanjutkan: "Apa yang terjadi kalau matahari terbenam?

Sang bijak menjawab: "Bulan."

Dialog berlangsung dari matahari ke bulan, dari bulan ke api, dari api ke suara, dari suara ke jiwa. Jiwa itu berakar dalam Roh. Inilah advaita, non-dualitas, yang diajarkan para penganut aliran Upanishad. Menurut mereka, Yang Absolut/Allah dan dunia itu bukanlah dua. Mereka juga bukan satu. Diri manusia tidak melihat Yang Absolut itu sebagai "Other" (Yang Lain), melainjkan Diri yang lebih dalam. Seperti dikatakan oleh Paulus: "Bukan lagi aku yang hidup, melainkan Kristus yang hidup di dalam aku" (Gal 2:20).

The Silence of the Buddha (Keheningan Buddha): Buddha menolak untuk bicara tentang Absolut/Allah. Dia tidak menolak, dia juga tidak menerima Yang Absolut itu. Dia membuka mata terhadap lingkungannya: Ada orang sakit dan mati. Bagaimana membebaskan manusia dari pengalaman akan penderitaan itu. Menurutnya, keinginan (desire) merupakan biang kerok penderitaan. Agar bisa bebas dari penderitaan, orang harus bebas dari keinginan.

Buddha juga melihat bahwa segala sesuatu merupakan suatu "network of relationships" (sirkuit dengan banyak jejaring). Namun jejaring yang kompleks dalam sirkuit itu tidak bisa dialami. Mereka bukan obyek di luar sana, Mereka juga bukan subyek di dalam sini. Yang ada adalah hidup, benda-benda dan orangorang. Namun segala sesuatu berubah, dan tak satu pun yang tetap yang dapat kita lekatkan diri padanya. Yang ada hanyalah penderitaan, bukan pribadi yang menderita. Tidak seorang pun bertindak, yang ada adalah tindakan itu sendiri. Nirvana ada, 
namun tak seorang pun mencarinya. Ada jalan, namun tak seorang pun mengikuti jalan itu. Nirvana itu bukan nihilime. Yang terbaik adalah diam ketimbang berusaha menjelaskannya. Dalam keheningan kehidupan berlangsung seperti sebelumnya, namun orang perlu hidup tanpa melekatkan diri padanya.

\section{TINJAUAN KRITIS}

"Jika orang-orang bijak dari Timur itu benar, maka Santo Agustinus keliru," kata Ludwig Wittgenstein. "Mengapa Santo Agustinus," tanya Wittgenstein, "menyebut Tuhan di setiap halaman Confessions yang ditulisnya?" Namun, katanya, mereka semua tentu tidak salah jika tidak ada teori tertentu di balik semua itu. ${ }^{12}$

Masih dari Wittgenstein: Perhatikan permainan bahasa. Ada mitologi dalam bahasa. Lihatlah kemiripan-kemiripan dalam kata-kata yang digunakan. Don't think, just look, look closely! (Jangan berpikir, hanya lihat, lihatlah dekat-dekat!). Seperti mata

12 Awalnya "mitologi dalam bahasa" adalah sampah filsafat. Sampah ini dibuang karena dianggap sulit dan sangat kabur. Sampah ini adalah "Remarks on Frazer's The Golden Bough" catatan Ludwig Wittgenstein (1889-1951) tentang perdukunan dari seluruh dunia yang dihimpun oleh James G, Frazer (18541941). Catatan Wittgenstein tertanggal 19 Juni 1931 ini ditemukan setelah Wittgenstein meninggal dunia. Sampah filsafat ini menjadi berlian antropologi. Salah satu hal yang penting dari Wittgenstein adalah ini:"Frazer's representation of human magical and religious notions is unsatisfactory: it makes these notions appear as mistakes. Was Augustine mistaken, then, when he called on God on every page of the Confessions? But-one might say-if he was not in error, then surely was the Buddhist saint-or whoever else-whose religion expresses entirely different notions. But none of them was in error except where he was putting forth a theory." (Paparan Frazer tentang perdukunan dan gagasan-gagasan keagamaan itu tidak memuaskan: Paparan itu membuat gagasan-gagasan keagamaan tampak keliru. Apakah Agustinus keliru ketika dia menyebut Allah dalam setiap halaman Confessions? Namun - orang bisa mengatakan - jika Agustinus tidak keliru, maka orang bijak Buddhis keliru - atau orang bijak lainnya - yang agamanya mengungkapkan gagasan-gagasan yang berbeda. Namun, tidak satu pun dari mereka keliru, kecuali jika dia mulai dengan teori." Lih. Ludwig Wittgenstein, The Mythology in Our Language - Remarks on Frazer's Golden Bough, (Chicago: Hau Books, 2018), 32. Kutipan ini penting, bukan saja untuk mempertimbangkan teori macam apa yang dipakai dalam berteologi secara kontekstual, melainkan juga pembedaan roh secara jeli: Apakah teologi itu digerakkan oleh Spirit (Roh Allah sendiri) atau Ghost (roh yang lain). tidak melihat mata, demikian kata tidak mengatakan tentang dirinya sendiri. Seperti kalimat tidak mengalimatkan kalimat, demikian bahasa tidak membahasakan bahasa. Namun semua itu ada di sana. Just look! ${ }^{13}$

Pater Amaladoss memaparkan padangannya dengan sangat jelas, sangat ontologis, sangat obyektif, dan sangat perfek. Ada orang yang memang mampu menaklukkan semua di depan mata seobyektif mungkin. Ada juga orang yang mampu menaklukkan semua di belakang mata sesubyektif mungkin. Namun ada orang yang mengalami dan mengerti keduanya dalam keseharian hidup. Antara TO EXPERIENCE, EXPERIENCING, dan EXPERIENCE, Pater Amaladoss berada pada posisi experience. Bahkan para bijak Timur yang berada pada posisi to experience, Pater Amaladoss berhasil menggiring mereka ke posisi experience. Namun dalam keseharian hidup, manusia berada dalam posisi experiencing.

Dalam posisi experiencing, EXPERIENTALISTS (orang-orang yang sadar akan pengalaman yang melampaui pengertian) membidik gerund dalam data yang dilihat. Dalam gerund itu ada interaksi, dan dalam interaksi itu ada aksi-aksi yang menjelaskan pengalaman (experiencing) dan pengertian (understanding) tentang sesuatu dalam kaitan dengan sesuatu

\footnotetext{
3 Sudah sejak awal Perang Dunia Pertama Wittgenstein mengatakan bahwa mata tidak melihat dirinya sendiri. Lih. Ludwig Wittgenstein, Tractatus Logico-Philosophicus (London: Routledge and Kegan Paul, 1990), 151-153. Kemudian pada awal abad ke-21 Feldman menegaskan kembali hal ini ketika mengatakan bahwa kata tidak mengatakan tentang dirinya sendiri, kalimat tidak menyelaskan tentang dirinya sendiri. Lih. Jerome A. Feldman, "From Molecule to Metaphor," (Massachusetts: The MIT Press, 2006), 3-14. George Lakoff, penulis "Metaphor We Live By," menyegani Wittgenstein dan memuji Feldman. Lakoff menggunakan istilah "embodied" yang dibedakan dengan "embedded" untuk menegaskan bahwa "ide mencari tubuh" (body) agar penjelmaan bisa terjadi dan bukan seperti sistem yang membutuhkan suatu perangkat sebagai tempat tidur (bed) untuk diaplikasi dan diaktivasi.
} 
yang lain. EXPERIENTALISTS menyadari hal ini sebagai metaphorical concepts atau conceptual metaphors. Karena itu, pandangan yang sangat perfek dari Pater Amaladoss di atas perlu dibangkitkan kembali agar menjadi relevan dalam keseharian hidup.

Dua conceptual metaphors yang menjadi refleksi Pater Amaladoss adalah GOD'S SILENCE IS A CALL TO CONVERSION (keheningan Allah merupakan seruan untuk bertobat) dan GOD'S SILENCE IS A KIND OF TEST (keheningan Allah itu semacam ujian). Juga kutipan dari Galatia 2:20 - "And I live, now not I: but Christ liveth in me. And that I live now in the flesh: I live in the faith of the Son of God, who loved me and delivered himself for me." - mengandung sejumlah conceptual metaphors seperti ini: I AM DEAD, CHRIST IS ALIVE IN ME, I AM IN FLESH, I AM IN FAITH, THE SON OF GOD IS FOR ME.

Interaksi manusia dengan Allah -seperti interaksi Paulus dengan Yesus -tidak sedemikian jauh sampai tak-terlihat mata dan tak-terdengar telinga. Paulus menghayati interaksi itu dalam keseharian hidupnya. Interaksi itu membuat Paulus mati dan Yesus Kristus hidup di dalam diri Paulus sendiri. Paulus berubah: Walaupun masih memiliki tubuh (somebody), Paulus hidup dalam iman. THE SON OF GOD IS FOR ME bukan mengerdilkan Putra Allah, melainkan sadar bahwa kenosis Sang Putra itu sangat altruistis. Sang Putra yang turun ke "neraka" adalah Sang Putra yang sama yang keluar dari sana, kata Hans Urs von Balthasar. ${ }^{14}$ Pengalaman subyektif yang sangat mendalam dari Putra manusia ini

\footnotetext{
Hans Urs von Balthasar, Mysterium Paschale - The Mystery of Easter (San Francisco: Ignatius Press, 1990). Pandangan ini dibahas pada "Solidarity in Death" dalam bab empat "Going to the Death: Holy Saturday."
}

menyentuh pengalaman terdalam dari penderitaan manusia. Di ujung kematian Paulus, di situlah kehidupan Kristus. "BEING FOR ME" dalam THE SON OF GOD IS FOR ME bisa diekspresikan dalam aksi-aksi seperti ini:

\section{THE SON OF GOD IS FOR ME}

\begin{abstract}
Aku mengejar orang Kristen, aku mengejar Kristus.
Aku menganiaya orang Kristen, aku menganiaya Kristus.

Aku tumbang, aku buta.

Aku mati, namun Kristus hidup dalam aku.

Aku diampuni, aku diutus untuk mewartakan tentang Dia.

Aku dikejar oleh musuh-musuhku, namun aku dilindungi.

Aku hanya ingin tahu tentang-Nya.

Aku dipenjarakan, dan akhirnya dipenggal.
\end{abstract}

Interaksi dengan Kristus itu mengubah Paulus. Dia menganiaya orang Kristen, dia menganiaya Kristus sendiri. Paulus kemudian mengalami dan mengerti berbagai aksi-aksinya itu dalam interaksi dia dengan Kristus. Bahwa aksi-aksi itu menunjukkan "semacam ujian" atau "seruan untuk bertobat," itu selalu mungkin. Dalam posisi experiencing dan understanding, aksi-aksi terjadi dalam waktu (time) yang melampaui ruang (space). Paulus wafat di Roma pada abad pertama Masehi, namun "history of tomorrow" (sejarah hari esok) adalah sejarah kehidupan Gereja dalam Alfa-Omega $(\mathrm{A} \Omega)$. Kristus datang dari masa depan, dan ke masa depan jugalah perziarahan Gereja dikisahkan.

\section{ALEPH}

Dalam A $\Omega$ (Alfa-Omega dalam bahasa Yunani yang dibaca dari kiri ke kanan) atau ת (Aleph-Tav dalam bahasa Ibrani yang dibaca dari kanan ke kiri), "melihat dengan mata" dan "mendengar dengan telinga" selalu bisa dilakukan dengan penuh kejelian dan discernment (semacam kejelian membedabedakan roh di balik semua fenomen): Ada 
bentuk-bentuk tertentu di sana. Jika bentukbentuk itu relevan, itu karena mereka membantu menjernihkan interaksi manusia dengan Sang Percipta. Namun di sini, saya akan lebih memusatkan perhatian pada aleph (א), karena abjad ini merupakan titik konvergen dari semua refleksi yang sangat diakronis di atas.

"Melihat dengan mata" dan "mendengar dengan telinga" pertama kali saya dengar ketika bersentuhan dengan eksegese Perjanjian Lama. Prof. Dr. Berthold Pareira mengatakan bahwa mempelajari Sabda Allah itu perlu ada suatu kepekaan rohani untuk "melihat dengan telinga" dan "mendengar dengan mata."15

Mendengar kedua ungkapan itu, hanya kebingungan menyelimuti pikiran saya kala itu. Telinga itu untuk mendengar (bukan untuk melihat), dan mata untuk melihat (bukan untuk mendengar). Namun ketika melihat komposisi tertulis (written composition) Kitab Suci dengan mata, bentuk (Gestalt) teks-teks itu mengatakan banyak hal untuk didengar telinga. Menyelidiki secara lebih mendalam tentang bentuk (Gestalt) dari teks (data) itu sendiri, kegiatan ini memberi informasi (Gestaltnya masuk ke dalam pikiran), memberi transformasi (Gestalt-nya mengubah cara berpikir), dan memberi performasi (Gestaltnya mengubah cara bertindak). Ketika mendengar pewartaan Kitab Suci sebagai komposisi lisan (oral composition) dengan telinga, bentuk-bentuk itu muncul sebagai gambaran-gambaran dalam benak untuk dilihat.
Ketika berkenalan dengan abjad pertama bahasa Ibrani yaitu aleph ( $),{ }^{16}$ "melihat dengan telinga" (seeing through ear atau seeing voice) dan "mendengar dengan mata" (listening through eyes atau hearing vision), ternyata sudah menjadi hal yang biasa dan mendasar bagi pemilik huruf ini -- aleph (※). Yang sangat mendasar yaitu mereka sudah terbiasa berpikir dengan abjad, bukan dengan kata.

Huruf aleph (א) itu sudah sangat mendidik mereka untuk "mendengar dengan mata." Tanpa aleph (א), emet (תמא) menjadi mat (תמ). Kata "emet" (alephmem-tav) dan "mat" (mem-tav) berbeda hanya karena aleph. Tanpa aleph ( $)$, kebenaran (emet) itu mati (mat). AlephTav (ת) sebagai jendela kebenaran adalah Alfa-Omega (A $\Omega$ ) itu sendiri. Ketika mata melihat huruf ini, telinga menangkap suara kehidupan. Kebenaran dan kehidupan menjadi satu. Dalam ruang visual, telinga menangkap suara kehidupan. Atau mungkin lebih tepat: Telinga kehidupan menangkap suara kehidupan.

Bagi yang "melihat dengan telinga," mendengar "aleph" dan "eleph" orang melihat dua hal yang berbeda dari abjad aleph ( $\times)$ yang sama. Tuturan "aleph" tetap mengacu abjad aleph ( $\aleph$ ) dengan nilai numeriknya satu, sedangkan tuturan "eleph" yang juga mengacu pada abjad aleph (※) yang sama, nilai numeriknya seribu. Apakah ini yang Yesus maksudkan ketika mengatakan bahwa bagi Allah seribu tahun sama dengan satu hari? Entahlah! Namun yang jelas, pemilik bahasa Ibrani sudah

$16 \quad$ Bagi orang Yahudi: Tidak bisa menulis $\mathrm{N}$ (aleph) berarti buta huruf.
"Kepekaan rohani" yang dimaksud itu, menurut kami, lebih terkait dengan pengalaman (experiencing) ketimbang pengertian (understanding). Karena itu dalam makalah ini kami enggan membahas "kepekaan" tersebut secara khusus. 
terbiasa untuk "melihat dengan telinga." Mata manusia Ibrani melihat dunia lewat ruang auditorial (ruang pendengaran), seperti telinga mendengar tuturan lewat ruang visual (ruang penglihatan).

\section{Aleph -- (※) -- merepresentasikan} interaksi: YOD atas (artinya: tangan Allah) dan YOD bawah (artinya: tangan manusia) bertemu di VAV diagonal (artinya: paku). "Being nailed" (dipaku) sebagai bentuk gerund penting untuk mengkodifikasi aksiaksi apa saja yang terjadi dalam interaksi Allah dengan manusia. Dari interaksi Allah dengan manusia itu, "kerja sama" yang diprakarsai Allah juga mendapat respon manusia. Sekalipun demikian, baik Allah maupun manusia mengalami apa artinya dipaku (being nailed).

Interaksi Allah-manusia ini melahirkan konsep manusia tentang Allah sebagai יהוה (YHVH atau YHWH = Tuhan) yang selalu bekerja (bdk. Yoh 5:17). Pada saat יהוה berinteraksi dengan $\mathrm{N}$, maka aleph menemukan YHVH sebagai sumber pemaknaan bagi karya tangan manusia. Dengan kata lain: YHVH menjadi source domain (locus) bagi aleph sebagai target dimain (focus):

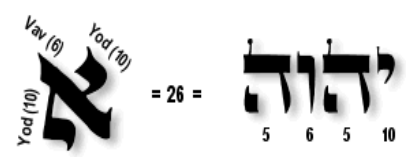

Gematria $^{17}$ penghubung aleph dengan YHVH ini mendasari hikmah kabbalah: "before aleph cames beit" (beit mendahului aleph). ${ }^{18}$ Di sini teologi mendapat locus

\footnotetext{
Lih. https://www.hebrew4christians.com/Names_of_G-d/ Esoteric/aleph-p2.gif. Gematria adalah nilai numerik dari huruf-huruf. Jika dua hal memiliki nilai numerik yang sama - seperti halnya aleph dan YHVH - maka ada kesamaan (metafora) dan keserupaan (simile) dari kedua hal tersebut.

18 Elliot R. Wolfson, Alef, Mem, Tau - Kabbalistic Musing on Time, Truth, and Death (Berkeley: University of California Press, 2006), 118. YOD HE VAV HE (YHVH) merupakan keyakinan yang mendasari arsitektur rumah. Bagi orang Yahudi, huruf
}

(ruang) yang memungkinkan teolog (manusia) berteologi - Ursprung dan Anfang diekspresikan secara gamblang. Ada Anfang (awal mula) untuk setiap aksi. Namun tanpa Ursprung (asal-usul), Anfang (YHVH) bisa mengelabui manusia. Tanpa Ursprung, suami-istri bisa menjadi orangtua yang baik, namun apakah mereka bisa menjadi "katekis keluarga" yang baik? Tanpa Ursprung, seorang mahasiswa yang cerdas bisa menjadi filsuf atau teolog yang baik, namun apakah filsafat atau teologinya cukup theistic dan bukan atheistic?

Ursprung (aleph) dan Anfang (YHVH) tidak ada masalah bagi Allah, namun bagi manusia perlu kejelian dan discerment di hadapan Allah. Bentuk (form, Gestalt) itu seperti ladang: Bisa ditaburi gandung oleh tuan ladang itu di siang hari dan lalang oleh musuhnya di malam hari (bdk. Mat 13:2425).

Rabbi Yitzchak Ginsburgh mengatakan, YHVH (Y = Bapa, H = Ibu, V = Putra, $\mathrm{H}=$ Putri) itu keluarga. ${ }^{19}$ Mengatakan ALLAH ITU KELUARGA sama saja dengan mengatakan "יהוה = $"$ "י YHVH (יהוה) menjadi source domain (sumber pemaknaan) bagi aleph. YHVH (יהוה) menjadi atribut bagi aleph. YHVH (יהוה) menjadi pengalaman dan pengertian akan

beit (rumah) - huruf kedua dalam abjad Ibrani -- merupakan huruf pertama dalam Kitab Suci. Ini berarti sejak semua Allah sudah berumah bersama manusia, dan hubungan Allah dengan manusia adalah seperti hubungan keluarga dalam rumah. Bagaimana bisa demikian?

19 Rabbi Yitzchak Ginsburgh, What You Need to Know About Kabbalah (Jerusalem: Gal Einai, 2006), 131. Ketika Tuhan menciptakan manusia menurut gambar dan keserupaan-Nya (Kej 1:26), maka empat titik pada YHVH itu dihubungkan empat titik pada citra manusia, maka keluarga Allah dan keluarga manusia membentuk sebuah rumah berupa kubus dengan 12 garis yang mewakili 12 suku Israel dalam Perjanjian Lama dan 12 rasul dalam Perjanjian Baru. Bentuk rumah ini masih terlihat dalam bentuk tabernakel dalam Gereja Katolik dan arsitektur rumah tradisional orang Yahudi. Arsitektur rumah dan keluarga yang menghuninya merupakan bidang studi antropologi budaya yang sangat penting untuk berteologi secara kontekstual. Yang juga menarik adalah bahwa Israel itu Putri Allah. Kemudian Gereja Katolik juga melihat dirinya sebagai Putri Allah. 
aleph. Di sini, penulis Surat Efesus (dan saya yakin, dia adalah Santo Paulus) pasti seorang kabbalis. Dia menempatkan misteri (mysterium magnum) di antara keluarga mikro (keutuhan suami-istri) dan keluarga makro (keutuhan Kristus-Jemaat). ${ }^{20}$ Dia memasukkan Ursprung ke dalam Anfang sehingga keluarga mikro (keutuhan suamiistri) tidak kehilangan asal-usulnya (aleph). Dia memasukkan aleph ke dalam interaksi insani. Dia menempatkan aleph dalam YHVH (יהוה). Maksudnya: Jika YHVH (יהוה) tidak menampakkan aleph, maka semua interaksi dalam YHVH (יהוה) dalam keluarga (ayah-ibu-putra-putri) itu hanyalah Anfang tanpa Ursprung. Jika demikian, maka teologi semacam itu hanyalah sebuah teologi ateistik. Tanpa Ursprung (aleph), Anfang (YHVH) menjadi perdukunan agamis. Tanpa aleph, kebenaran menjadi kematian.

\section{MODEL KATEKESE KELUARGA}

Model katekese yang kami usul di sini adalah "Model Katekese Aleph." Ketika wabah Covid-19 menjadi pandemi, semua kegiatan terpusat di rumah (domus). Gagasan "ecclesia domestica" ("keluarga itu Gereja" yang berbeda dengan "Gereja itu keluarga") menjadi penting. Namun banyak orangtua tidak merasa bahwa mereka adalah "katekis keluarga," karena mereka tidak pernah mengenyam pendidikan kateketik, karena itu cukup bagi mereka jika bisa mengirim anak-anak ke lembaga pendidikan Katolik untuk mendapat katekese dari para katekis. Lantas, pendidikan iman untuk anak usia 0-5 tahun yang belum dikirim ke sekolah itu urusan siapa? Ada beberapa orangtua yang mengatakan: "Ah, biarkan saja! Anakanak itu toh akan menyesuaikan diri dengan sendirinya." Jadi orangtua membiarkan anaknya.
Jika "mukjizat adalah anak emas dari iman," maka orangtua yang membiarkan anaknya itu mungkin adalah orangtua yang baik, namun sebagai orangtua Katolik yang terikat kewajiban memberi pendidikan iman kepada anaknya berdasarkan Sakramen Perkawinan (bukan Sakramen Pembaptisan) dalam ecclesia domestica, mereka adalah "katekis keluarga yang buruk." Mereka adalah teolog "ecclesia domestica" - konsep Gereja yang terkait dengan Sakramen Perkawinan. Mungkin mereka sangat beriman, namun jika mereka mengabaikan "anak emas" (mukjizat) dari iman itu sendiri, maka katekis keluarga yang buruk.

Dalam "Criteria for Catechesis" yang dikeluarkan oleh Komisi Katekese dan Evangelisasi dari Konferensi Waligereja Kanada tahun 2015, setelah Sinode Para Uskup di Roma dan sebelum Paus Fransiskus mengeluarkan Seruan Apostolik "Amoris Laetetia” (2016), tema katekse untuk anak usia 0-5 tahun adalah "In the image and Likeness of God" (Dalam Gambar dan Rupa Allah).

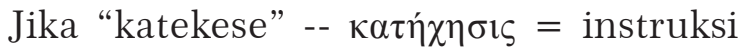
lisan yang keluar dari mulut - hanya dimaknai sebagai tindakan orangtua mengajar anaknya dengan bahasa lisan, maka memang tidak perlu ada katekese untuk anak usia 0-5 tahun. Namun anak usia 0-5 tahun di Kanada tidak lebih cerdas dari anak usia 0-5 tahun di belahan bumi lainnya. Pemerolehan bahasa (language acquisition) untuk anak-anak normal usia 0-5 tahun itu tidak ada perbedaan besar di manamana. Pada usia sedini itu, justru orangtua perlu menjadi "murid" anaknya. Anak usia dini yang belum bisa baca-tulis tidak bisa menjadi murid untuk diberi instruksi lisan. Yang terjadi pada usia dini ini adalah "translanguaging." Ada aksi-aksi berbahasa 
dalam interaksi orangtua dengan anaknya. Orangtua mereka-reka bahasa anaknya. Anak-anak berusaha mengungkapkan sesuatu dengan bunyi-bunyi yang kurang bermakna karena keterbatasan biologisnya: Mulai dengan bunyi-bunyi, suku-suku kata, kata-kata yang tidak lengkap dalam kalimat sederhana, sampai pada kalimat-kalimat sederhana, anak-anak berusaha untuk berbahasa seiring perkembangan biologisnya. Selain itu, untuk situasi urban: Sejak usia dini, anak sudah terbiasa berkenalan dengan berbagai bahasa lewat orangtuanya maupun internet. Interaksi orangtua-anak itu membuat translanguaging menjadi takterelakkan: Bahasa dikembalikan ke subyek (orangtua dan anak). Orangtua maupun anak belajar berbahasa (languaging) dan belajar berinterinteraksi dengan berbahasa (translanguaging).

Di sini, orangtua tidak bisa menjadi "katekis keluarga" dalam pengertian "guru," melainkan dalam pengertian "murid." Orangtua "belajar" menjadi katekis dari anaknya. Anaknya adalah data atau teks yang hidup dan suci. Orangtua adalah "murid" dari anaknya, orangtua adalah "murid" dari teks, orangtua adalah "murid" bahasa, orangtua belajar melihat bentuk.

Model-model katekese yang ada adalah model "pengajaran" (teaching). Model Katekese Aleph adalah model "pembelajaran" (learning). Perggulatan manusia dalam "translanguaging" menuntut pembelajaran yang lebih serius ketimbang pengajaran. Bahasa - dari "imago" (matafora) dan "similitudo" (simile) - akan terus berkembang dan akan merembes ke berbagai aspek kehidupan. Berangkat dari pengalaman menuju pengamalan mungkin baik dijadikan "struktur berkatekese" (structure of doing catechesis) bagi katekis keluarga. Dari belajar melihat bentuk, katekis keluarga bisa menerapkan bentuk itu dalam ecclesia domestica.

Pada bahasa, bentuk itu berawal dari abjad-abjad. Tradisi semitik berpengaruh besar bagi pemeluk agama Islam dan penganut agama Kristen di dunia umumnya dan di Indonesia khususnya. Bagi umat Kristen, khususnya Katolik, interaksi Allah-manusia selalu perlu dilihat pada Kristus dalam kaitan dengan aleph, abjad pertama bahasa Ibrani yang sangat kaya akan makna ini. Yesus yang "sungguh Allah, sungguh manusia itu” merentangkan kedua tangannya untuk dipaku. Tangan Allah dan tangan manusia dipaku. Being nailed (dipaku) menunjukkan suatu interaksi Allah-manusia yang pernah terjadi dan sedang terjadi dalam drama kehidupan orang Kristen. Praksis dramatik tidak meleset dari aleph ( $)$.

Aleph (*) memiliki nilai numerik yang sama dengan יהוה (YHVH = Tuhan). Sekalipun demikian, KELUARGA ITU ALLAH יהוה) א) dan ALLAH ITU KELUARGA (יהוה = איה (יהוה) merupakan dua metafora konsepsual sangat berbeda, bahkan bertentangan. Metafora KELUARGA ITU ALLAH merupakan metafora yang atheistic. Sedangkan metafora ALLAH ITU KELUARGA merupakan metafora yang theistic.

Metafora atheistic -- (יהוה) -- sangat berbahaya. Tak seorang teolog Katolik pun yang berani menyatakan bahwa KELUARGA ITU ALLAH. Namun kenyataannya, demi keluarga, orang berani melakukan apa saja. Demi kelompok, orang bisa menjadikan dirinya sebagai penguasa di atas segalagalanya. Demi negara, orang bisa saling membunuh. Demi agama, orang berani memanipulasi Allah. Dari keluarga paling mikro sampai ke keluarga paling makro, Allah dijadikan mainan. Jika KELUARGA 
ITU ALLAH, maka "keluarga" menjadi target, "Allah" menjadi sumber permainan manusia di tangannya sendiri.

Metafora theistic -- (יהוה = א א -- sangat penting bagi ecclesia domestica. Demi Allah, orang berani melakukan apa saja agar Allah dimuliakan. Demi Allah, orang berani mengorbankan apa saja termasuk dirinya sendiri agar Allah dimuliakan. Demi Allah, orang berani meninggalkan keluarganya agar Allah semakin dikenal. Demi Allah, orang bisa membangun keluarga dengan baik agar Allah dimuliakan. Jika ALLAH ITU KELUARGA, maka "Allah" menjadi target dan "keluarga" menjadi sumber pengabdian manusia di tangan Allah. Namun interaksi dua tangan di paku pada huruf aleph (א) menjadi taruhan: Allah macam apa yang Anda cintai dan muliakan.

Pada saat "beit mendahului aleph" -תישארב (bereshit = "pada mulanya") - dalam ayat pertama Kitab Suci (Kej 1:1), orang Yahudi sadar bahwa tidak ada penciptaan tanpa Anfang (aksi). Selain itu huruf beit (yang berarti "rumah") menunjukkan bahwa tindakan (aksi) itu terjadi dalam ruang yang jelas yaitu rumah. Namun aksi itu dilakukan oleh Ursprung, dan bukan oleh manusia karena manusia belum diciptakan.

Setelah diciptakan, manusia menyadari bahwa sejaksemula Allah sudahingin serumah dengan manusia. Namun menurut refleksi kabbalis, ketika berdosa manusia mengusir Allah dari dalam rumah. Posisi Allah dalam rumah diambil-alih manusia, dan manusia menjadi Allah dalam rumah. Ketika Putra Allah menghampakan diri menjadi manusia (kenosis), manusia menuduh Putra Allah sebagai makluk celaka karena "manusia kok mau jadi Allah." Sepintas kilas, tuduhan ini seakan-akan menunjukkan sikap kesalehan. Namun, ketika didalami, biang tuduhan itu bisa ditemukan juga: Allah tidak berdaya, dan manusia menenggelamkan diri dalam keberdayaannya insaninya sendiri. Menolak Ursprung berarti terperangkap dalam Anfang. Di sinilah "teologi atheistic" bertumbuh. Di sinilah "teologi maut" berkembang.

Katekese keluarga bermula dari keluarga, mulai dari rumah (beit). Namun katekese keluarga berasal dari Allah. Awal mulanya (Anfang) memang יהוה (YHVH) namun asalusulnya (Ursprung) adalah $\times($ aleph). Tanpa Ursprung, sia-sialah Anfang. "Unless the Lord build the house, they labour in vain that build it. Unless the Lord keep the city, he watcheth in vain that keepeth it" (Mzm 127:1). ${ }^{21}$ Katekese keluarga bertumpu pada metafora ini: ALLAH ITU KELUARGA -- ( $=$ יהוה $)$.

"Model Katekese Aleph" bertumpu pada interaksi tangan Allah dengan tangan manusia dipaku (being neiled). Apakah manusia berorientasi ke Allah, ataukah Allah berorientasi ke manusia, being nailed merepresentasikan kerja sama yang menyakitkan. Kerja sama (interaksi) ini mengandung banyak aksi. Dalam belajar menjadi katekis, "katekis keluarga" (orangtua) perlu mengalami dan mengerti aksi-aksi ini ketika mereka bekerja sama dengan Allah untuk mendidik anak-anak mereka, anak-anak Allah sendiri. Bekerja sama dengan Allah, katekis mengajar. Hidup bersama dengan anak-anak Allah, orangtua belajar. Dikatakan oleh Yesus dalam Injil Matius: “... bertobat dan menjadi seperti

"Jikalau bukan Tuhan yang membangun rumah, maka mereka yang membangunnya telah berjerih lelah dengan sia-sia; jikalau bukan Tuhan yang menjaga kota, maka sang penjaga telah berjaga dalam kesia-siaan" (Maz 127:1). Tuhan itu memang terjemahan dari $\mathrm{YHVH}$, namun $\mathrm{YHVH}$ juga berarti keluarga (Ayah-lbu-Putra-Putri) yang terkait dengan beit (rumah). 
anak kecil... serta ... merendahkan diri dan menjadi seperti anak kecil ...." (Mat 18:34) bisa dipelajari oleh orangtua yang hidup bersama anak-anak Allah - teks yang hidup dan suci - yaitu anak usia 0-5 tahun.

Bekerja sama dengan Allah itu ada tujuannya. Tujuan itu jelas dalam Surat Paulus yang dikutip oleh Hans Urs von Balthasar untuk mengakhiri "Mysterium Paschale," karyanya yang terkenal itu:

"Sebab tidak ada seorangpun di antara kita yang hidup untuk dirinya sendiri, dan tidak ada seorangpun yang mati untuk dirinya sendiri. Sebab jika kita hidup, kita hidup untuk Tuhan, dan jika kita mati, kita mati untuk Tuhan. Jadi baik hidup atau mati, kita adalah milik Tuhan. Sebab untuk itulah Kristus telah mati dan hidup kembali, supaya Ia menjadi Tuhan, baik atas orang-orang mati, maupun atas orang-orang hidup" (Rm. 14:7-9).

\section{PRAKSIS KATEKESE ALEPH DALAM "ECCLESIA DOMESTICA"}

Dalam "ecclesia domestica," praksis "Katekese Aleph" adalah drama kehidupan orangtua itu sendiri sebagai "katekis keluarga." Sebagai "murid" dari anaknya (= teks yang hidup dan suci), aleph bukan mata pelajaran yang rumit. Kerumitan - jika ada - ditangguhkan saja dalam keheningan untuk belajar melihat bentuk secara jeli.

Aleph hanyalah sebuah huruf hening (silent letter), bukan kata, bukan kalimat, bukan kitab. Namun suara kehidupannya bisa ditangkap oleh telinga kehidupan. Tanpa aleph (א), kebenaran (emet - תמא itu mati (mat - ת) .
Gereja Katolik telah mengondisikan keluarga-keluarga Katolik dengan hal-hal sederhana. Salib berkorpus dipasang di ambang pintu atau di kamar tidur. Ibuibu Katolik yang sederhana telah terbiasa membuat tanda salib dan memegang tangan anaknya untuk membuat tanda yang sama. Namun semua itu perlu dilihat sebagai aksi-aksi yang keluar dari interaksi Allahmanusia.

Gestalt (bentuk) semua teologi adalah liturgi: Allah menguduskan manusia, manusia memuliakan Allah. Dalam "Keluarga Gereja" (artinya: Gereja itu keluarga), bentuk teologi adalah ritus sakramental yang uniform (seragam). Dalam "Gereja Keluarga" (artinya: Keluarga itu Gereja), bentuk teologi adalah ritual kehidupan yang pluriform (aneka ragam).

Baik "ritus" maupun "ritual," kebiasaan ini dilakukan berulang-ulang kali sehingga berjalan otomatis. Namun kedua bentuk ini - ritus maupun ritual -- tidak meleset dari interaksi Allah-manusia. Sakramen Pembaptisan membuat setiap orang mengambil bagian dalam kenabian Kristus: Seorang nabi tidak pernah memikirkan Allah tanpa manusia, dan tidak pernah memikirkan manusia tanpa Allah. ${ }^{22}$ Namun Sakramen Perkawinan membuat interaksi Allah-manusia itu terjadi dalam ecclesia domestica. Inti kesadaran ini ada pada aleph («). Agar menjadi praktis, aleph perlu diposisikan dalam praksis, dalam "TheoDrama" menurut bahasa Hans Urs von Balthasar. Mungkin tiga hal ini membantu untuk menjadikannya ritual kehidupan:

\footnotetext{
22 "For Heschel, a pillar of authentic prophecy was the prophet's ability to hold God and man in one thought at one time" (Bagi Heschel, pilar otentik nubuat adalah kemampuan nabi berpegang teguh pada Allah dan manusia dalam satu pikiran dan waktu secara serempak), kata Susannah Heschel tentang keyakinan ayahnya, Abraham Joshua Heschel - teolog Yahudi yang berperan penting di balik dokumen Konsili Vatikan II "Nostra Aetate." Lih. https://www.plough.com/en/topics/ community/leadership/two-friends-two-prophets
} 
Pertama, aleph itu sederhana: Belajar memberi bentuk kepada iman. Ulurkan telunjuk bukan untuk menunjuk melainkan untuk disentuh dan dipegang oleh anak. YOD atas (tangan Allah) melakukan itu kepada YOD bawah (tangan manusia). Anak mendengar kasih ketika matanya menatap aleph. Anak menjadi aleph itu sendiri ketika dia menjadi penghubung ayah-ibunya. Anak-anak tidak perlu dibawa ke Kapel Sistina di Roma untuk melihat lukisan Michaelangelo tentang "Penciptaan Adam." Bagi orangtua Katolik, membuat tanda salib atau memegang tangan anaknya untuk membuat tanda salib sudah menunjukkan bentuk yang nyata tentang aleph. Bentuk itu mungkin saja kosong karena dilakukan tanpa kesadaran rohani apapun. Namun kesadaran rohani akan aleph membutuhkan bentuk yang selalu dipelajari dalam sikap doa, ketika manusia berbicara dengan Tuhan.

Kedua, aleph itu relevan: Orangtua yang belajar menjadi katekis maupun katekis yang belajar menjadi orangtua akan banyak menimba kekayaan dari aleph. Bagi orangtua yang mau menjadi "katekis keluarga," belajar pada aleph itu penting untuk bisa menjadi "murid" dari anaknya sendiri. Anak akan mengajarkan bagaimana iman itu diejawantah (embodied) dalam setiap ritual keseharian hidup. Artinya: Beri tubuh kepada iman, beri bahasa kepada pikiran, beri ritual kepada teologi. Bagi katekis yang mau menjadi "orangtua dalam ecclesia domestica," belajar pada aleph akan sangat menolong untuk memberi "roh kehidupan" kepada semua perbendaharaan katektik. Artinya: Beri iman kepada tubuh (segala teknik dan model katekese yang telah dikuasai dan dipraktekkan). Dalam berbagai aksi ini, Allah berbicara dan manusia belajar mendengar.
Ketiga, aleph adalah atraktif: Anakanak tertarik dengan permainan, musik, gambar, gerak, warna-warni, simbol-simbol dan bahkan benda-benda karena semua ini berbentuk. Anak-anak usia dini tidak butuh posisi epistemik (yang benar dan yang salah berdasarkan pertimbangan logos). Anakanak juga tidak tertarik pada posisi etik (yang baik dan yang buruk berdasarkan pertimbangan ethos). Anak-anak justru tertarik pada posisi gramatik (yang indah dan yang jelek berdasarkan pertimbangan pathos). Karena itu pathos anak perlu juga dipelajari dalam kaitan dengan pathos Allah sendiri. ${ }^{23}$

"Model Katekese Aleph" ini sebenarnya untuk anak ataukah orangtua? Model katekese ini untuk orangtua Katolik (beriman) yang tidak meninggalkan anaknya (mukjizat) sebagai yatim piatu. "Mukjizat adalah anak emas dari iman." ALLAH ITU ECCLESIA DOMESTICA. Jika ecclesia domestica itu hidup dan suci, dia mengejawantah Allah sendiri. Inilah drama kehidupan. Sekalipun dramatik (tanpa perlu didramatisasi), namun aleph menunjukkan bahwa YOD atas (tangan Allah) selalu terulur ke YOD bawah (tangan manusia) untuk tetap menjalin kerjasama Allah-manusia dalam drama kehidupan. Sedramatik apapun keseharian hidup, interaksi Allah-manusia akan tetap menjadi kekuatan Allah bagi manusia, juga ketika orangtua menjadi "murid" anaknya untuk belajar menjadi "katekis keluarga" dalam ecclesia domestica.

\footnotetext{
23 "The great secret is God's hidden pathos." (Rahasia agung adalah pathos Allah yang tersembunyi). Abraham J. Heschel, The Prophets (New York: HarperCollins, 2001), 61 8. Me-review "The Propher," Sephen Barkley mengatakan, "The pathos of God is his heart of God for man, which takes on various forms such as 'love and anger, grief and joy, mercy and wrath'." (Pathos Allah adalah kasih-Nya -- Allah untuk manusia, yang terungkap dalam aneka bentuk seperti "cinta dan marah, sedih dan gembira, kasih dan murka.") Lih. https://stephenbarkley. com/2016/08/01/prophets-abraham-j-heschel/
} 


\section{DAFTAR RUJUKAN}

Amaladoss, Michael, Silence and God, dalam "Silence," Concilium 2005/5. London: SCM Press, 2015.

Balthasar, Hans Urs von, Mysterium Pascale. USA: Ignatius Press, 2006.

Derrida, Jacques, Of Grammatology. Baltimore: The Johns Hopkins University Press, 1997),

Feldman, Jerome A., From Molecule to Metaphor. Massachusetts: The MIT Press, 2006.

Ginsburgh, Rabbi Yitzchak, What You Need To Know About Kabbalah. Jerusalem: Gal Einai, 2006).

Halliday, M.A.K. "Functional Grammar," (London: Routledge, 2014).

Harari, Yuval Noah, "Homo Deus: Masa Depan Umat Manusia," (Jakartra: Alvabet, 2018).

Heschel, Abraham J. The Prophets, (New York: HarperCollins, 2001),

https://www.hebrew4christians.com/Names of_G-d/Esoteric/aleph-p2.gif. https://www.plough.com/en/topics/community/ leadership/two-friends-two-prophets

https://stephenbarkley.com/2016/08/01/prophets-abraham-j-heschel/

Roberts, Matthew. A Historical Survey and Conceptual Account of States of Affairs, Ph.D. Dissertation. Denver: University of Colorado, 2006.

Rosenzweig, Franz. "Der Stern der Erlösung," Freiburg: Freiburg im Breisgau, Universitätsbibliothek, 2002.

Rosenzweig, Franz. The Star of Redemption, Wisconsin: The University of Wisconsin Press, 2005.

Wittgenstein, Ludwig. The Mythology in Our Language - Remarks on Frazer's Golden Bough, Chicago: Hau Books, 2018.

Wittgenstein, Ludwig, Tractatus Logico-Philosophicus, London: Routledge and Kegan Paul, 1990.

Wolfson, Elliot R., Alef, Mem, Tau - Kabbalistic Musing on Time, Truth, and Death. Berkeley: University of California Press, 2006. 